\title{
Molecular analysis and expression of the lipase of Staphylococcus epidermidis
}

\author{
Angela M. Farrell, ${ }^{1 *}$ Timothy J. Foster ${ }^{2}$ and Keith T. Holland ${ }^{1}$ \\ ${ }^{1}$ Department of Microbiology, University of Leeds, Leeds LS2 9JT, UK \\ ${ }^{2}$ Department of Microbiology, Moyne Institute, Trinity College, Dublin 2, Ireland
}

(Received 1 June 1992; revised 14 September 1992; accepted 8 October 1992)

\begin{abstract}
Lipase of Staphylococcus epidermidis 9 was purified from culture supernatant fluid. Two polypeptides (51 and $43 \mathrm{kDa}$ ) were detected by SDS-PAGE, of which the $43 \mathrm{kDa}$ polypeptide reacted with anti-lipase serum. The $S$. epidermidis 9 lipase gene (gehC) was cloned in Escherichia coli and localized to a $2.1 \mathrm{~kb}$ sequence by subcloning and transposon mutagenesis. The nucleotide sequence of gehC (2064 nucleotides) was determined and the predicted amino acid sequence of the encoded lipase $(77 \mathrm{kDa}$ ) identified. A $97 \mathrm{kDa}$ lipase was detected in extracts of $E$. coli harbouring $g e h C$ and in post-exponential-phase culture supernatant fluids of $S$. epidermidis 9. Data presented indicate that the lipase behaves anomalously during SDS-PAGE and that a pro-lipase is proteolytically processed in cultures of $S$. epidermidis 9 during growth.
\end{abstract}

\section{Introduction}

Staphylococcus epidermidis is the most prevalent and persistent Staphylococcus species on human skin and is present in large numbers over much of the skin area (Kloos, 1990). Staphylococci secrete extracellular enzymes which may have evolved as scavenging enzymes, degrading polymeric material (proteins, lipids, nucleic acids and polysaccharides) in the environment. These may provide a survival advantage by releasing low molecular mass compounds for growth (Arvidson, 1983).

Until recently, coagulase-negative staphylococci, such as $S$. epidermidis, were not considered to be important in causing disease and their presence in clinical specimens was considered to be due to contamination. In contrast, Staphylococcus aureus is an important pathogen causing a wide range of infections in man and other animals. As a result, attention has been directed to $S$. aureus and the coagulase-negative staphylococci have been studied much less. Recently, S. epidermidis has assumed greater importance in infections associated with implanted medical devices (Pulverer et al., 1987). Coagulasenegative staphylococci are ideally situated to cause infections in such compromised hosts because of their

*Author for correspondence. Tel. (0532) 335615; fax (0532) 335638.

The nucleotide sequence data reported in this paper have been submitted to GenBank and have been assigned the accession number M95577. prevalence on the skin. The role of various extracellular enzymes in infections caused by $S$. epidermidis is unclear. Factors which have been implicated include $\alpha$ - and $\beta$ haemolysins, lipases and proteases, in addition to cell components which promote adherence to host cell surfaces (Baird-Parker, 1990).

The advent of molecular cloning methodology has facilitated the study of various staphylococcal gene products as putative virulence determinants. Mutants of $S$. aureus, deficient in $\alpha$-haemolysin and protein A, have been constructed by allele replacement, allowing comparative studies with otherwise isogenic strains in animal models (O'Reilly et al., 1986; Patel et al., 1987).

As part of a programme to study the physiological and pathological role of $S$. epidermidis extracellular enzymes, lipase (EC 3.1.1.3) was chosen for study. Physiological studies comparing a lipase-deficient mutant with an otherwise isogenic strain would provide information concerning the role of the enzyme in staphylococcal nutrition and colonization. The initial stages of allele replacement, namely the cloning and expression of an $S$. epidermidis lipase gene (gehC) in Escherichia coli are described in this communication. The sequence of gehC and lipase expression in $S$. epidermidis cultures are also reported.

\section{Methods}

Bacterial strains, plasmids and phages. An isolate from the volar forearm, designated strain 9 , was identified as $S$. epidermidis by the 
Table 1. Bacterial strains

\begin{tabular}{|c|c|c|}
\hline Strain & Genotype and relevant properties & Source or reference \\
\hline $\mathrm{C} 600$ & lac thr leu thi tonA hsdR hsdM & Appleyard (1954) \\
\hline $\mathrm{XAcSu}^{-}$ & $\begin{array}{l}\text { Dlac-pro }{ }_{\text {vIIII }} \text { ara argE thi rif nal } \mathrm{Su}^{-} ; \text {non- } \\
\text { suppressing host for } \mathrm{Tn} 5 \text { mutagenesis with } \\
\lambda 467\end{array}$ & Coleman \& Foster (1981) \\
\hline TG1 & $\begin{array}{l}\text { Alac pro supE thi hsdD5 } / \mathrm{F}^{\prime} \text { traD36 proA } A^{+} B^{+} \\
\text {lac }{ }^{q} \text { AlacZM } 15\end{array}$ & Wain-Hobson et al. (1985) \\
\hline DS410 & $\min A \min B \operatorname{rps} L ;$ minicell producer & Dougan \& Sherratt (1977) \\
\hline XL-1 Blue & 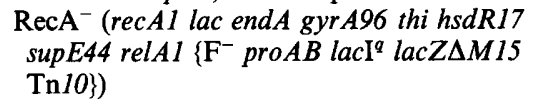 & Stratagene \\
\hline
\end{tabular}

Table 2. Plasmids

\begin{tabular}{|c|c|c|c|}
\hline Plasmid & Markers & Other relevant properties & Reference \\
\hline pBluescript & $\mathrm{Ap}^{\mathrm{r}}$ & Cloning vector & Stratagene \\
\hline pBR322 & $\mathrm{Ap}^{\mathrm{r}} \mathrm{Tc}^{\mathrm{r}}$ & Cloning vector & Bolivar et al. (1977) \\
\hline $\mathrm{pIC} 20 \mathrm{H}$ & $\mathrm{Ap}^{\mathrm{r}}$ & Cloning vector & Marsh et al. (1984) \\
\hline pUL5000 & $\mathrm{Ap}^{\mathrm{r}}$ & $\begin{array}{l}2.5+1.2 \mathrm{~kb} \text { HindIII fragments from } \lambda g e h C \text { cloned in } \\
\text { pBR322 }\end{array}$ & \\
\hline pUL5001 & $A^{r}$ & $15.4 \mathrm{~kb} E c o$ RI fragment from $\lambda g e h C$ cloned in pBR 322 & \\
\hline pUL5003 & $A p^{r}$ & $2.5 \mathrm{~kb}$ HindIII fragment from pUL5000 in pIC20H & \\
\hline pUL5004 & $\mathrm{Ap}^{\mathrm{r}}$ & $1.2 \mathrm{~kb}$ HindIII fragment from pUL5000 in pIC20H & \\
\hline pUL5005 & $\mathrm{Ap}^{\mathrm{r}}$ & $1.55 \mathrm{~kb} E c o \mathrm{RV}$ fragment from pUL5000 in pIC $20 \mathrm{H}$ & \\
\hline pUL5007 & $\mathrm{Ap}^{\mathrm{r}}$ & $2.85 \mathrm{~kb}$ ClaI fragment from pUL5000 in pIC20H & \\
\hline pUL5008 & $\mathrm{Ap}^{\mathrm{r}}$ & $\begin{array}{l}\text { pUL } 5007 \text { with } 2.85 \mathrm{~kb} \text { ClaI fragment in opposite } \\
\text { orientation }\end{array}$ & This study \\
\hline pUL5009 & $\mathrm{Ap}^{\mathrm{r}}$ & $\begin{array}{l}2.85 \mathrm{~kb} \text { ClaI fragment from pUL5000 in pBluescript II } \\
\mathrm{KS}\end{array}$ & \\
\hline pUL5010 & $\mathrm{Ap}^{\mathrm{r}}$ & $\begin{array}{l}\text { pUL5009 with } 2.85 \mathrm{~kb} \text { ClaI fragment in opposite } \\
\text { orientation }\end{array}$ & \\
\hline $\begin{array}{l}\text { pUL5000 } \\
\text { gehC: :Tn5 }\end{array}$ & $\mathrm{Ap}^{\mathrm{r}} \mathrm{Km}^{\mathrm{r}}$ & Tn5 mutants deficient in lipase around colonies & \\
\hline
\end{tabular}

scheme of Kloos \& Schleifer (1975). E. coli strains and plasmids used in this study are shown in Tables 1 and 2, respectively.

Bacteriological media. E. coli strains were grown in $\mathrm{L}$ broth and on $L$ agar, and $\lambda$ phages were propagated on $\lambda$ base and top agar (Miller, 1972). E. coli DS410 was propagated in Brain Heart Infusion. For $S$. epidermidis 9 lipase production, modified forms of the synthetic medium of Taylor \& Holland (1989) were used. The media were designated medium A and medium B (Table 3).

Enzyme assays. Acid phosphatase was assayed as described by Ingham et al. (1985). Proteinase was assayed as described by Ingham $e t$ al. (1985) except the reaction mixture comprised $1 \%(\mathrm{w} / \mathrm{v})$ azocasein in $0.2 \mathrm{M}$-MOPS ( $\mathrm{pH} \mathrm{7.4)}$ ) and the incubation time was $2 \mathrm{~h}$. One unit of proteinase is defined as that amount which causes an increase in $A_{440}$ of $0.001 \mathrm{~h}^{-1}$. Lipase was assayed as described by Ingham et al. (1981) except an emulsion of $20 \%(\mathrm{w} / \mathrm{v})$ triolein and $20 \%(\mathrm{w} / \mathrm{v})$ gum arabic emulsified in $0.2 \mathrm{M}$-Tris/ $\mathrm{HCl}(\mathrm{pH} 7.5)$ was used as the substrate and the incubation time was $10 \mathrm{~min}$. One unit of lipase activity is defined as that amount which releases $1 \mu \mathrm{mol}$ oleic acid $\mathrm{min}^{-1}$.

Production of lipase. S. epidermidis was grown in $6 \times 500 \mathrm{ml}$ volumes of medium $\mathrm{A}$ in 2-litre baffle flasks for $6 \mathrm{~h}$ with orbital shaking at
160 r.p.m. at $37^{\circ} \mathrm{C}$. Cultures were centrifuged $(5200 \mathrm{~g}, 10 \mathrm{~min})$ and the supernatant fluid was filtered through $0.2 \mu \mathrm{m}$ porosity filters. The filtrate was stored at $4^{\circ} \mathrm{C}$.

Purification of $S$. epidermidis lipase. All procedures were carried out at $0-4^{\circ} \mathrm{C}$.

(a) Ultrafiltration. Filtered culture supernatant fluid was concentrated by ultrafiltration with a PM10 Diaflo membrane (cut-off, $10 \mathrm{kDa}$ ) and desalted by diafiltration.

(b) Anion-exchange chromatography. Concentrated lipase was applied to a DEAE-Sepharose column $(1.6 \times 22 \mathrm{~cm})$ pre-equilibrated with $50 \mathrm{~mm}-\mathrm{Tris} / \mathrm{HCl}(\mathrm{pH} \mathrm{7.8})$. Fractions were eluted with $100 \mathrm{ml}$ $50 \mathrm{~mm}$-Tris/ $\mathrm{HCl}(\mathrm{pH} \mathrm{7.8)}$ followed by a linear salt gradient $(0-1.5 \mathrm{M}$ $\mathrm{NaCl}, 300 \mathrm{ml}$ ) at a flow rate of $24 \mathrm{ml} \mathrm{h}^{-1}$. Fractions with a constant specific lipase activity were pooled and lyophilized.

(c) Gel-filtration chromatography. Lyophilized lipase was reconstituted in distilled water and applied to a Sephadex G-100 column $(1.6 \times 25 \mathrm{~cm})$ pre-equilibrated with $50 \mathrm{mM}-\mathrm{Tris} / \mathrm{HCl}(\mathrm{pH} 7.0)$. Fractions were eluted at a flow rate of $6.3 \mathrm{ml} \mathrm{h}^{-1}$ in the same buffer. The column was calibrated with Blue Dextran 2000, bovine serum albumin $(66 \mathrm{kDa})$, carbonic anhydrase $(29 \mathrm{kDa})$ and cytochrome $c(12.4 \mathrm{kDa})$ (Sigma). Fractions from the Sephadex G-100 column with the highest specific activity were pooled and applied to a Sephadex G-25 column 
Table 3. Composition of synthetic media

\begin{tabular}{|c|c|c|}
\hline \multirow[b]{2}{*}{ Component } & \multicolumn{2}{|c|}{ Final concn $\left(\mathrm{g} \mathrm{l}^{-1}\right)$} \\
\hline & Medium A & Medium B \\
\hline L-Alanine & $2 \cdot 40$ & $9.60 \times 10^{-1}$ \\
\hline L-Arginine & $3.6 \times 10^{-1}$ & $1.44 \times 10^{-1}$ \\
\hline L-Aspartic acid & $2 \cdot 40$ & $9.60 \times 10^{-1}$ \\
\hline L-Cystine & $2.4 \times 10^{-1}$ & $9.6 \times 10^{-2}$ \\
\hline L-Glutamic acid & $2 \cdot 40$ & $9.60 \times 10^{-1}$ \\
\hline Glycine & $2 \cdot 40$ & $9.60 \times 10^{-1}$ \\
\hline L-Histidine & $4.8 \times 10^{-1}$ & $1.92 \times 10^{-1}$ \\
\hline L-Isoleucine & $6.0 \times 10^{-1}$ & $2.40 \times 10^{-1}$ \\
\hline L-Leucine & $6.0 \times 10^{-1}$ & $2.40 \times 10^{-1}$ \\
\hline L-Lysine & $6.0 \times 10^{-1}$ & $2.40 \times 10^{-1}$ \\
\hline L-Methionine & $1.8 \times 10^{-1}$ & $7.2 \times 10^{-2}$ \\
\hline L-Phenylalanine & $2.0 \times 10^{-1}$ & $8.0 \times 10^{-2}$ \\
\hline L-Proline & $2 \cdot 40$ & $9.60 \times 10^{-1}$ \\
\hline L-Serine & $2 \cdot 40$ & $9.60 \times 10^{-1}$ \\
\hline L-Threonine & $2 \cdot 40$ & $9.60 \times 10^{-1}$ \\
\hline L-Tryptophan & $6 \times 10^{-2}$ & $2.4 \times 10^{-2}$ \\
\hline L-Tyrosine & $1.8 \times 10^{-1}$ & $7 \cdot 2 \times 10^{-2}$ \\
\hline L-Valine & $4.8 \times 10^{-1}$ & $1.92 \times 10^{-1}$ \\
\hline Nicotinic acid & $2.0 \times 10^{-2}$ & $2.0 \times 10^{-2}$ \\
\hline Biotin & $6 \times 10^{-5}$ & $6 \times 10^{-5}$ \\
\hline Thiamin. $\mathrm{HCl}$ & $9.0 \times 10^{-3}$ & $9.0 \times 10^{-3}$ \\
\hline $\mathrm{MgSO}_{4} \cdot 7 \mathrm{H}_{2} \mathrm{O}$ & $2.5 \times 10^{-1}$ & $4.93 \times 10^{-2}$ \\
\hline $\mathrm{ZnCl}_{2}$ & $3.4 \times 10^{-3}$ & $6.8 \times 10^{-4}$ \\
\hline $\mathrm{CuSO}_{4} \cdot 5 \mathrm{H}_{2} \mathrm{O}$ & $5 \times 10^{-4}$ & $1.0 \times 10^{-4}$ \\
\hline $\mathrm{MnSO}_{4} \cdot 4 \mathrm{H}_{2} \mathrm{O}$ & $5.6 \times 10^{-3}$ & $1.12 \times 10^{-3}$ \\
\hline $\mathrm{NaCl}$ & $5.8 \times 10^{-3}$ & $1.16 \times 10^{-3}$ \\
\hline $\mathrm{CaCl}_{2} \cdot 2 \mathrm{H}_{2} \mathrm{O}$ & $5 \cdot 0 \times 10^{-3}$ & $1.00 \times 10^{-3}$ \\
\hline $\mathrm{CoCl}_{2} \cdot 6 \mathrm{H}_{2} \mathrm{O}$ & $2.4 \times 10^{-3}$ & $4.8 \times 10^{-4}$ \\
\hline $\mathrm{FeCl}_{3} \cdot 6 \mathrm{H}_{2} \mathrm{O}$ & $2.7 \times 10^{-2}$ & $5.4 \times 10^{-4}$ \\
\hline $\mathrm{KH}_{2} \mathrm{PO}_{4}$ & $1 \cdot 34$ & $1 \cdot 34$ \\
\hline $\mathrm{Na}_{2} \mathrm{HPO}_{4}$ & $5 \cdot 70$ & $5 \cdot 70$ \\
\hline$\left(\mathrm{NH}_{4}\right)_{2} \mathrm{SO}_{4}$ & $5 \cdot 00$ & $2 \cdot 00$ \\
\hline Glucose & $4 \cdot 00$ & $2 \cdot 00$ \\
\hline
\end{tabular}

$(1 \times 13 \mathrm{~cm})$. Fractions were eluted at a flow rate of $14.4 \mathrm{ml} \mathrm{h}^{-1}$ in distilled water.

(d) Cation-exchange chromatography. Lipase was applied to a CMSepharose column $(1 \times 10 \mathrm{~cm})$ pre-equilibrated with $50 \mathrm{~mm}$-sodium phosphate buffer ( $\mathrm{pH} 7 \cdot 0$ ). Fractions were eluted in the same buffer at a flow rate of $30 \mathrm{ml} \mathrm{h}^{-1}$ and, after $20 \mathrm{ml}$ had eluted, a linear salt gradient was applied $(0-0.5 \mathrm{M}-\mathrm{NaCl}, 40 \mathrm{ml})$. Lipolytic fractions were stored at $-20^{\circ} \mathrm{C}$.

Protein assay. Elution of protein from chromatography columns was monitored at $280 \mathrm{~nm}$. Protein concentration was determined by the method of Bradford (1976), using bovine serum albumin as the standard.

SDS-PAGE. SDS-PAGE was performed using $7.5 \%(\mathrm{w} / \mathrm{v})$ gels as described by Laemmli (1970). The molecular mass standards (Sigma) were carbonic anhydrase $(29 \mathrm{kDa})$, egg albumin $(45 \mathrm{kDa})$, bovine albumin $(66 \mathrm{kDa})$, phosphorylase $b(97.4 \mathrm{kDa}), \beta$-galactosidase $(116 \mathrm{kDa})$ and myosin $(205 \mathrm{kDa})$. Proteins were visualized using the GELCODE Silver Staining System (Pierce). Western immunoblotting was carried out with the Pharmacia Novablot apparatus as described in the manual. After electrophoresis, proteins were transferred to nitrocellulose and blots were developed as described by Russell et al. (1985).

Antisera. Antiserum was raised against purified lipase from the cation-exchange column. Lipase doses $(50 \mu \mathrm{g})$ were administered to New Zealand White rabbits using the multiple inoculation regime of
Ingham et al. (1984). The antiserum was absorbed with a concentrated extract of $E$. coli $\mathrm{C} 600$ before use. Horseradish-peroxidase-conjugated swine anti-rabbit globulins were from Dakopatts.

DNA manipulations. Restriction endonucleases and other enzymes were obtained from Pharmacia or Gibco/BRL and used according to the manufacturers' instructions. A library of $S$. epidermidis 9 genomic DNA was constructed in the replacement vector, $\lambda$ L47.1, as described by O'Toole \& Foster (1986), except that genomic DNA was partially cleaved with $M b o I$, and $\lambda$ L47.1 was digested with BamHI. DNA manipulations were performed using standard procedures (Maniatis $e t$ al., 1982).

The $2.85 \mathrm{~kb}$ fragment of pUL5000 was subcloned into pBluescript II (KS) in both orientations, forming pUL5009 and pUL5010, and deletions were generated with exonuclease III and mung bean nuclease. The nucleotide sequence was determined by the dideoxynucleotide method of Sanger et al. (1977) using $\left[{ }^{35}\right.$ S $] \mathrm{dATP}$ and T7 DNA polymerase.

Screening of recombinant phages for lipase production. Recombinant phages were plated on $E$. coli $\mathrm{C} 600$ and plaques were overlaid with $7 \mathrm{ml}$ tributyrin agar, comprising 3 vols $1 \%$ (w/v) Agar no. 1 (Oxoid) in $50 \mathrm{mM}$-Tris/ $\mathrm{HCl}(\mathrm{pH} 7.5)$ and 1 vol. tributyrin emulsion $(4 \%, \mathrm{v} / \mathrm{v}$, tributyrin and $0.4 \%, \mathrm{w} / \mathrm{v}$, polyvinyl alcohol emulsified in $50 \mathrm{~mm}$ Tris/ $\mathrm{HCl}, \mathrm{pH} 7 \cdot 5$ ). After $18 \mathrm{~h}$ incubation at $37^{\circ} \mathrm{C}$, recombinant phages from presumptive lipolytic plaques (zone of clearing above plaques) were purified, plated on $E$. coli $\mathrm{C} 600$ and overlaid with $5 \mathrm{ml}$ triolein agar comprising 20 vols Blood Agar Base (Oxoid), containing $30 \mu \mathrm{g}$ $\mathrm{ml}^{-1}$ Victoria Blue B (Difco), and 1 vol. triolein emulsion $(20 \%$, w/v, triolein and $4 \%, w / v$, gum arabic emulsified in distilled water). Lipaseexpressing recombinants were indicated by a blue zone above plaques after $24 \mathrm{~h}$ at $37^{\circ} \mathrm{C}$.

Screening of colonies for lipase production. Tributyrin agar comprised 24 vols 2 TY [1\%, w/v, Tryptone; $1 \%$, w/v, Yeast Extract; $1 \%, w / v$, Agar no. 1 (components from Oxoid) and $0.5 \%, \mathrm{w} / \mathrm{v}, \mathrm{NaCl}]$ and 1 vol. tributyrin emulsion $(20 \%, \mathrm{v} / \mathrm{v}$, tributyrin and $2 \%, \mathrm{w} / \mathrm{v}$, polyvinyl alcohol emulsified in distilled water). Triolein agar was prepared as described for screening phages. Lipolytic activity was indicated by a zone of clearing and a zone of blue precipitation around colonies on tributyrin and triolein agars, respectively, after $24 \mathrm{~h}$ at $37^{\circ} \mathrm{C}$.

Plaque immunoblotting. Lipase-expressing $\lambda$ plaques were detected as described by Russell et al. (1985). The nitrocellulose was sequentially incubated with anti-lipase serum and peroxidase-conjugated swine anti-rabbit immunoglobulins.

Immunochemical analysis of lipase. Extracts of plasmid-carrying strains were prepared by osmotic shock, as described by Neu \& Heppel (1965). Proteins were separated by SDS-PAGE, subjected to Western blotting and blots were developed as described for plaque immunoblotting.

Transposon mutagenesis. Transposon $\mathrm{Tn} 5$ insertion mutagenesis was performed by infecting $E$. coli $\mathrm{XAcSu}^{-}$carrying pUL5000 with $\lambda 467$ as described previously (Coleman \& Foster, 1981). Lipase-negative mutants were detected on tributyrin and triolein agars containing ampicillin $\left(100 \mu \mathrm{g} \mathrm{m}^{-1}\right)$ and kanamycin $\left(50 \mu \mathrm{g} \mathrm{m}^{-1}\right)$.

Nucleotide sequence analysis. Sequence alignments were performed using the multiple sequence alignment CLUSTAL 4 (Higgins \& Sharp, 1989), on an IBM AT-compatible microcomputer.

Minicells. E. coli DS410 was transformed with plasmids, and minicells were prepared and labelled as described by Dougan \& Sherratt (1977). Plasmid-encoded polypeptides were analysed by SDSPAGE and autoradiography using ${ }^{14} \mathrm{C}$-labelled molecular mass standards (Amersham). 

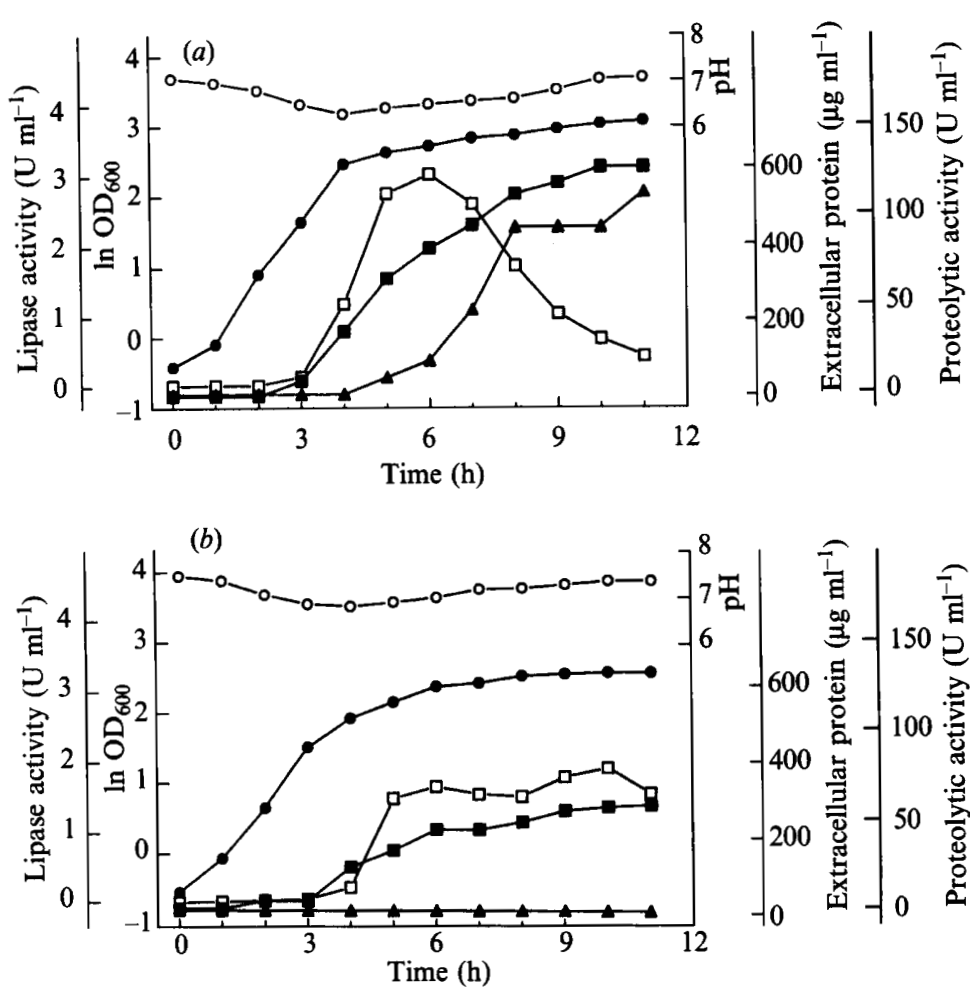

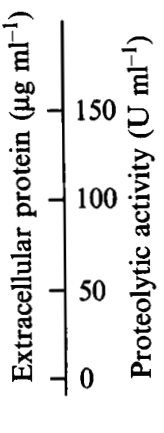

Fig. 1. Growth of, and extracellular product formation by, $S$. epidermidis 9 in $(a)$ medium $\mathrm{A}$ and $(b)$ medium B. $O, \ln \mathrm{OD}_{600} ; \mathrm{O}, \mathrm{pH} ; \mathbf{\Delta}$, proteinase; $\square$, lipase; $\square$, extracellular protein.

\section{Results}

\section{Purification of S. epidermidis lipase}

A defined synthetic medium (medium A) was employed as the growth medium for the production of $S$. epidermidis 9 lipase for purification. Maximum specific lipase activity [14 U (mg protein $\left.)^{-1}\right]$ was produced after $6 \mathrm{~h}$ incubation (Fig. 1a). Culture supernatant fluid was filtered and concentrated 18 -fold by ultrafiltration. Subsequent chromatography of this material on DEAESepharose resulted in two peaks of lipase activity, with $93 \%$ eluting without binding to the column. Proteinase and acid phosphatase bound to the column and eluted with 0.84 and $0.73 \mathrm{M}-\mathrm{NaCl}$, respectively. Fractions with highest specific activity of unbound lipase were combined and subjected to Sephadex G-100 chromatography. Lipase eluted as a broad peak of activity, with an apparent molecular mass of $60-200 \mathrm{kDa}$. Fractions with highest specific lipase activity (corresponding to $80 \mathrm{kDa}$ ) were combined, desalted and applied to a CM-Sepharose column. The lipase bound to the cation-exchange and eluted with $0 \cdot 17 \mathrm{M}-\mathrm{NaCl}$. The final purification factor was ninefold with a $1 \%$ yield.

Two polypeptides, of 43 and $51 \mathrm{kDa}$, were observed when the material from the cation-exchange column was analysed by SDS-PAGE and silver staining. Only the $43 \mathrm{kDa}$ polypeptide was detected when the material was analysed by Western immunoblotting with anti-lipase serum.

\section{Cloning of lipase gene in E. coli}

A method, employing the substrates tributyrin and triolein, was developed for detecting lipase-expressing recombinant phages. Tributyrin was used as the primary screen due to its high sensitivity to lipase activity, although it is nonspecific. Triolein was used as a confirmatory screen as it is specific for lipase. Recombinant phages from the $S$. epidermidis gene library $\left(1.4 \times 10^{7}\right.$ p.f.u. $\left.\mathrm{ml}^{-1}\right)$ were screened for lipase activity by overlaying plaques with tributyrin agar. Zones of lipolysis were observed above $0 \cdot 1 \%$ of the plaques after overnight incubation. Lipase activity was confirmed using triolein agar, and by plaque immunoblotting with anti-lipase serum. One of the phages, designated $\lambda g e h C$, was chosen for further study.

\section{Subcloning of gehC}

The HindIII fragments of $\lambda g e h C$ were subcloned into the HindIII site of pBR322 in E. coli C600 and lipolytic transformants were detectd on tributyrin and triolein agars. Analysis of plasmid DNA revealed two HindIII fragments $(2.5$ and $1.2 \mathrm{~kb})$ which were contiguous in $\lambda$ gehC (Fig. 2). One of the transformants was selected for further study and the plasmid designated pUL5000. Lipase activity was detected in concentrated culture supernatant fluids and periplasmic extracts of $E$. coli C600 harbouring pUL5000 [0.13 and 0.12 U (mg 


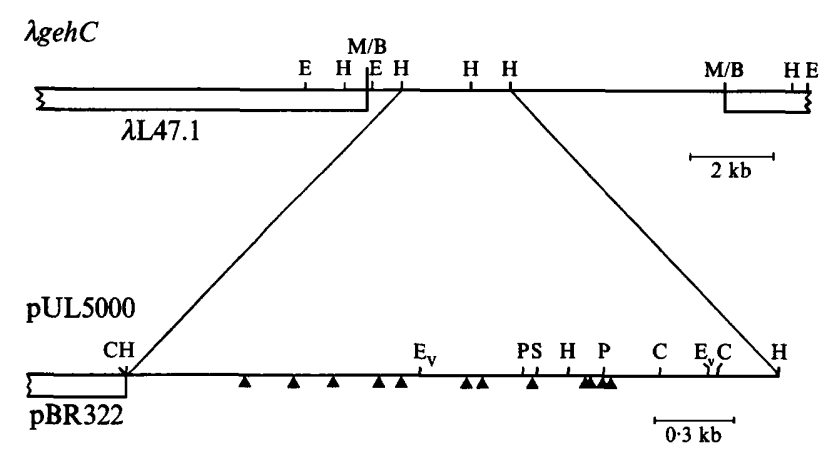

Fig. 2. Map of the cloned lipase gene. The thin line represents cloned $S$. epidermidis 9 sequences in $\lambda g e h C$ and pUL5000. The triangles show the location of $\operatorname{Tn} 5$ insertions. Restriction endonuclease cleavage sites are abbreviated as follows: B, BamHI; C, ClaI ; E, EcoRI; $\mathrm{E}_{\mathrm{v}}$, EcoRV; H, HindIII; M, MboI ; P, PvuII; S, SphI. Only the EcoRI and HindIII sites were mapped in $\lambda g e h C$.

protein $)^{-1}$, respectively]. Lipase activity was not detected in equivalent samples from $E$. coli harbouring pBR322.

To further localize gehC in pUL5000, a series of subclones was constructed. The $2.85 \mathrm{~kb} C l a \mathrm{I}$ fragment from pUL5000 was subcloned into the ClaI site of pIC20H in E. coli TG1, and plasmids with the insert in both orientations were identified (pUL5007 and pUL5008). High levels of lipase were expressed by E. coli TG1 harbouring pUL5008 in the presence of IPTG, whereas lower levels were produced in the presence of glucose and absence of IPTG, as detected by the colony assay. Low levels of lipase were also expressed from pUL5007 and expression was not affected by IPTG or glucose. These results suggest that both the lac and gehC promoters contribute to expression of lipase from pUL5008, whereas expression from pUL5007 is dependent only on the gehC promoter.

To localize gehC more precisely, twelve independent Tn5 insertion mutations which prevented the expression of lipase from pUL5000 were mapped. The mutations covered $2 \cdot 1 \mathrm{~kb}$ and spanned the central HindIII fragment (Fig. 2).

To confirm the Tn5 insertion mutagenesis data, the $2.5 \mathrm{~kb}$ HindIII fragment was cloned into the HindIII site of pIC20H in E. coli TG1. Lipase was expressed only when the fragment was in one orientation (pUL5003). The $1.2 \mathrm{~kb} H$ indIII and $1.55 \mathrm{~kb} E c o \mathrm{RV}$ fragments of pUL5000 were ligated to HindIII- and EcoRV-cleaved pIC20H, respectively, forming pUL5004 and pUL5005. These plasmids did not express lipase activity in $E$. coli TG1.

\section{Nucleotide sequencing}

The nucleotide sequence of the $2.85 \mathrm{~kb}$ ClaI fragment encoding $g e h C$ was determined in both orientations. A single open reading frame of 2064 nucleotides which encodes a protein of 688 amino acid residues with a predicted molecular mass of $77 \mathrm{kDa}$ was identified (Fig. 3 ). The Tn 5 insertion mutations are located in this open reading frame. It is likely that the GTG codon at position 121-123 nucleotides is the translational start site, even though GTG is used very rarely, because a potential ribosome-binding site (AGAGGTG) is located 7 nucleotides upstream and the predicted amino acid sequence of the resulting protein shows homology with other staphylococcal lipases (Fig. 4) (Gotz et al., 1985; Lee \& Iandolo, 1986). The locations of putative -35 (TTGGAT) and -10 regions (TAATAT) are shown in Fig. 3.

The pattern of codon usage is similar to other staphylococcal genes, with a strong bias towards A and U nucleotides in the wobble positions (Gotz et al., 1985; Phonimdaeng et al., 1990).

The hydropathy profile of the predicted $\mathrm{N}$-terminal amino acid sequence indicates the presence of a signal sequence. A short hydrophilic sequence (2-12 residues) is followed by a longer hydrophobic sequence (13-31 residues) and ends in Ala-Gln-Ala, an expected sequence preceding the cleavage site for a signal peptidase (Perlman \& Halvorson, 1983).

\section{Comparison of gehC with other lipases}

The aligned amino acid sequences of the $S$. epidermidis, $S$. hyicus and $S$. aureus lipases are shown in Fig. 4. The $\mathrm{N}$-terminal regions are distantly related, as indicated by the predominance of conserved residues. The $\mathrm{C}$-terminal regions, arbitrarily starting at the lysine residue indicated in Fig. 4, are closely related, with $43 \%$ of the 386 residues being identical and $35 \%$ being conservative changes.

A nine-residue segment containing some hydrophobic residues and the consensus sequence Gly- $\mathrm{X}_{1}-\mathrm{Ser}-\mathrm{X}_{2}$-Gly, where $X_{1}$ is Tyr or His, has been identified in all known microbial and mammalian lipase sequences. The location of this segment in the sequence of $S$. epidermidis lipase is shown in Fig. 4. The serine residues in the Mucor miehei and human pancreatic lipases are part of a Ser..His...Asp catalytic triad structurally related to trypsin (Brady et al., 1990; Winkler et al., 1990). It will be interesting to note whether the staphylococcal lipases are similar in this respect.

\section{Analysis of gehC-encoded proteins in E. coli}

Periplasmic extracts of E. coli harbouring pUL5000 and pUL5008 contained an immunoreactive protein of $97 \mathrm{kDa}$ which was not detected in extracts of cells harbouring $\mathrm{pBR} 322, \mathrm{pIC} 20 \mathrm{H}$ or $\mathrm{pUL} 5000$ gehC::Tn5 


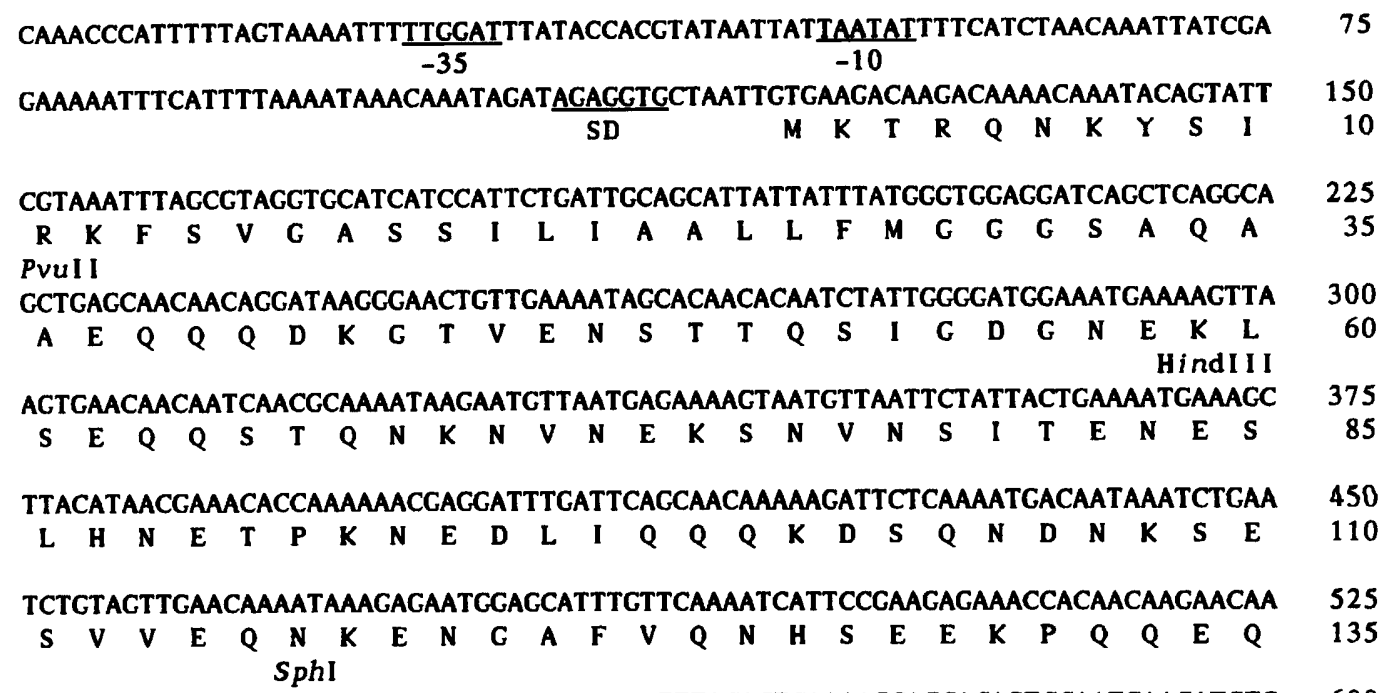
GTTGAACTGCAAAAGCATGCTAGTGAAAACAATCAAACTTTACACTCAAAAGCAGCACAGTCCAATCAACATGTG 600 $\begin{array}{lllllllllllllllllllllllllll}\mathbf{V} & \mathbf{E} & \mathbf{L} & \mathbf{E} & \mathbf{K} & \mathbf{H} & \mathbf{A} & \mathbf{S} & \mathbf{E} & \mathbf{N} & \mathbf{N} & \mathbf{Q} & \mathbf{T} & \mathbf{L} & \mathbf{H} & \mathbf{S} & \mathbf{K} & \mathbf{A} & \mathbf{A} & \mathbf{Q} & \mathbf{S} & \mathbf{N} & \mathbf{E} & \mathbf{D} & \mathbf{V} & & 160\end{array}$ PvuI I
AAAACTAAACCTTCACAACTCGATAATACAGCTCCCAAACAAGAAGACTCTCAAAAAGAGAATTTGAGTAAACAA 675 $\begin{array}{lllllllllllllllllllllllllll}\text { K } & \text { T } & K & \text { P } & \text { S } & Q & \text { L } & \text { D } & \text { N } & \text { T } & \text { A } & \text { A } & \text { K } & \text { Q } & \text { E } & \text { D } & \text { S } & \text { Q } & \text { K } & \text { E } & \text { N } & \text { L } & \text { S } & \text { K } & \text { Q } & & 185\end{array}$ GATACACAATCATCTAAAACTACTCATTTACTACGAGCAACACCTCAAAATCAATCAAAAGATAGCCAATCAACA 750

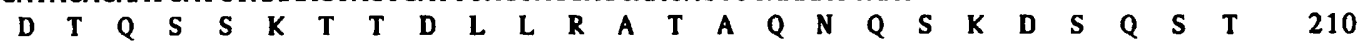
GAAGAGATAAATAAACAAGTAAATAACGACACTCAACAAGTGACTGCTAAGAACGATGACGCCAAAGTTCAATCA 825

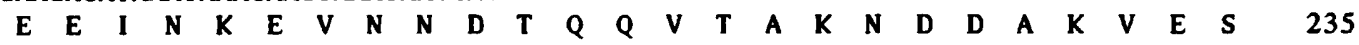

TTTAATTTAAATAGTAAAGAGGAACCCCTTAAAGTTGACAAGCAAGCGAATCCAACTACAGATAAAGATAAATCT 900 $\begin{array}{lllllllllllllllllllllllllll}\text { F } & \text { N } & \text { L } & \text { N } & \text { S } & \text { K } & \text { E } & \text { E } & \text { P } & \text { L } & \text { K } & \text { V } & \text { D } & \text { K } & \text { Q } & \text { A } & \text { N } & \text { P } & \text { T } & \text { T } & \text { D } & \text { K } & \text { D } & \text { K } & \text { S } & & 260\end{array}$ TCTAAAAATCATAAAGCGTCTCAAGATCGTCTCCCTAATTTAGAAAGTAATCCTCTTCCTACAACTAATAAACAG 975

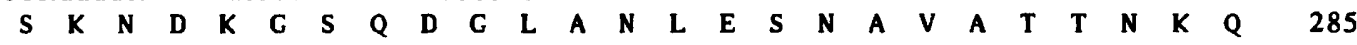
TCTAAGCAACAAGTGAGTGAAAAAAATGAGCATCAAACAAATAAATCACCAAAACAAAAACAATATAAAAATAAT 1050 $\begin{array}{llllllllllllllllllllllllll}S & K & Q & Q & V & S & E & K & N & E & D & Q & T & N & K & S & A & K & Q & K & Q & Y & K & N & N & 310\end{array}$ $E C O R V$
GATCCAATTATTTTAGTACATCGTTTCAATGGATTTACAGACGATATCAACCCATCAGTGCTAACGCATTATTGG 1125

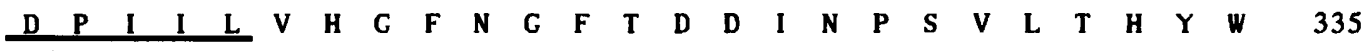
GGTGCCGATAAAATGAATATTCGCCAACATTTGGAAGAAAATGGATATCAGGCTTATGAAGCAAGTATAACTGCA 1200

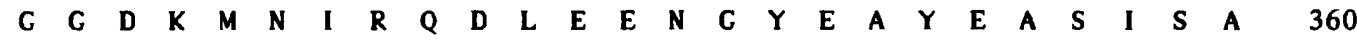
TTTGGTAGTAACTATGACCGTCCTGTTGAGTTATACTACTACATCAAAGGTCCACGTGTTGACTATGGTCCAGCA 1275

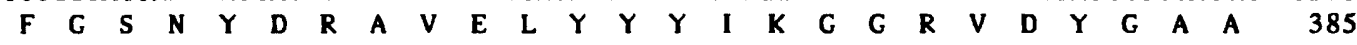
CACGCAGCTAAATATGCTCATGAGCGTTACGGTAAAACCTATCAAGCTCTTTATAAAGATTGCAAACCAGGTCAA 1350 $\begin{array}{llllllllllllllllllllllllll}\text { H } & A & A & K & Y & G & \text { H } & \text { E } & R & \text { Y } & G & \text { K } & \text { T } & \text { Y } & \text { E } & \text { G } & \text { V } & \text { Y } & \text { K } & \text { D } & \text { W } & \text { K } & \text { P } & \text { G } & \text { Q } & 410\end{array}$

AAAATACATTTAGTTGGTCATAGTATGGGTGGTCAAACAATTCGTCAATTAGAAGACCTATTGAGACATGGTAAT 1425

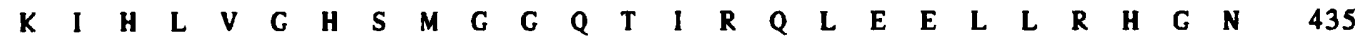
CCACAACAACTTCAATATCAAAAACAACATCGTCCGGAAATTTCTCCATTATACCAACCTGCCCACGACAATATC 1500 $\begin{array}{llllllllllllllllllllllllll}P & E & E & V & E & Y & Q & K & Q & H & C & C & E & I & S & P & L & Y & Q & C & C & H & D & N & M & 460\end{array}$ CTCTCATCTATTACAACACTCCCTACACCACATAATCCTACACATCCGTCACACTTATTACGTAACGAACCCATT 1575 $\begin{array}{lllllllllllllllllllllllllll}V & S & S & I & T & T & \text { L } & \text { C } & \text { T } & \text { P } & \text { H } & \text { N } & \text { G } & \text { T } & \text { H } & \text { A } & \text { S } & \text { D } & \text { L } & \text { L } & \text { G } & \text { N } & \text { E } & \text { A } & \text { I } & 485\end{array}$ GTACCCCAACTTCCATATGACGTACGTAAAATCTATGGTAATAAAGATTCACCTCTAGACTTTCCCTTAGAACAC 1650 $\begin{array}{llllllllllllllllllllllllll}\text { V } & R & Q & \text { L } & \text { A } & \text { Y } & \text { D } & \text { V } & \text { G } & \text { K } & \text { M } & \text { Y } & \text { C } & \text { N } & \text { K } & \text { D } & \text { S } & \text { R } & \text { V } & \text { D } & \text { F } & \text { C } & \text { L } & \text { E } & \text { H } & 510\end{array}$ 


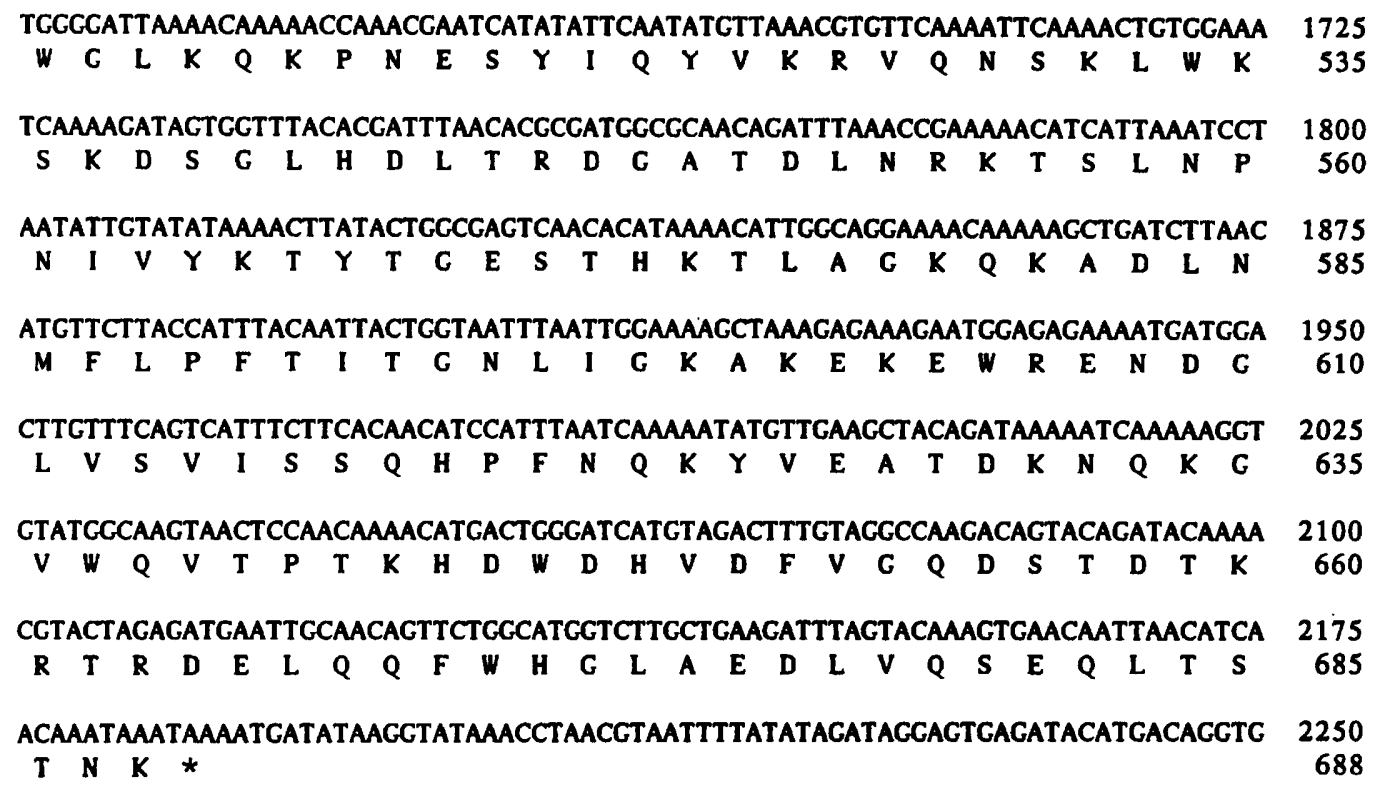

Fig. 3. Nucleotide sequence of the $S$. epidermidis 9 gehC gene and the deduced amino acid sequence of lipase. Putative $-35,-10$ and ribosome-binding site (SD) sequences are underlined (thin line). Restriction sites for PvuII, HindIII, SphI and EcoRV are indicated. The amino acid sequence obtained by sequencing the $\mathrm{N}$-terminus of the $43 \mathrm{kDa}$ lipase is underlined (thick line).

plasmids. A polypeptide of the same molecular mass was expressed, in addition to bla-encoded polypeptides, in $E$. coli minicells harbouring pUL5000 and pUL5008 (Fig. 5). The $97 \mathrm{kDa}$ polypeptide was not detected in extracts from $E$. coli minicells harbouring pBR322 or pUL5000gehC: : $\operatorname{Tn} 5$ plasmids.

\section{Expression of lipase in $S$. epidermidis}

Preliminary data indicated that a $97 \mathrm{kDa}$ lipase was produced by $S$. epidermidis 9 when medium B was used as the growth medium.

The growth kinetics and extracellular levels of lipase, proteinase and protein produced by $S$. epidermidis 9 in medium A and medium B are shown in Fig. 1. Lipase activity was detected in culture supernatant fluids during the post-exponential growth phase in both media.

In medium A, lipase activity increased to a maximum after $6 \mathrm{~h}$ incubation and declined thereafter. This was associated with an increase in proteolytic activity. The major polypeptides detected in Western immunoblots of supernatant fluids from cultures after 3-4 h incubation were 68,64 and $46 \mathrm{kDa}$. The 68 and $64 \mathrm{kDa}$ proteins were not detected after $4 \mathrm{~h}$ incubation. The levels of an additional polypeptide $(43 \mathrm{kDa})$ increased throughout growth to a maximum after $8 \mathrm{~h}$ incubation (Fig. 6).

In medium $\mathrm{B}$, lipase activity remained relatively constant after reaching a maximum after $6 \mathrm{~h}$ incubation. Proteins of 97, 64 and $46 \mathrm{kDa}$ were detected in culture supernatant fluids by Western immunoblotting (Fig. 6) and proteolytic activity was not detected.

\section{Identification of $S$. epidermidis lipase}

In addition to the observation that antiserum which neutralized lipase activity reacted with the $43 \mathrm{kDa}$ polypeptide in Western immunoblotting, the latter was identified as lipase by $\mathrm{N}$-terminal amino acid sequencing. The location of the N-terminus of the $43 \mathrm{kDa}$ lipase in relation to gehC is shown in Fig. 3. The predicted molecular mass of the lipase is $43.9 \mathrm{kDa}$, which agrees with that determined by SDS-PAGE. The N-terminal amino acid sequence of the $51 \mathrm{kDa}$ polypeptide (AIDDLTKVLNYTK) shows no homology to the predicted amino acid sequence of $S$. epidermidis lipase.

\section{Discussion}

In a defined synthetic medium, $S$. epidermidis 9 produced lipase, proteinase and acid phosphatase activities and more than 50 proteins were detected by SDS-PAGE. After purification, only lipase activity and two polypeptides were detected by SDS-PAGE and silver staining.

Purification of the lipase for antiserum production presented difficulties due to the nature of the lipase. Lipase species with molecular masses in the range $60-200 \mathrm{kDa}$ were observed during gel-filtration and this was probably due to aggregation. Lipases from several sources have ben shown to aggregate under certain conditions, forming high molecular mass forms (Kimura et al., 1972; Vadehra, 1974; Ingham et al., 1981), including an $S$. aureus lipase with a molecular mass of $43 \mathrm{kDa}$ by SDS-PAGE which aggregated to a $300 \mathrm{kDa}$ 


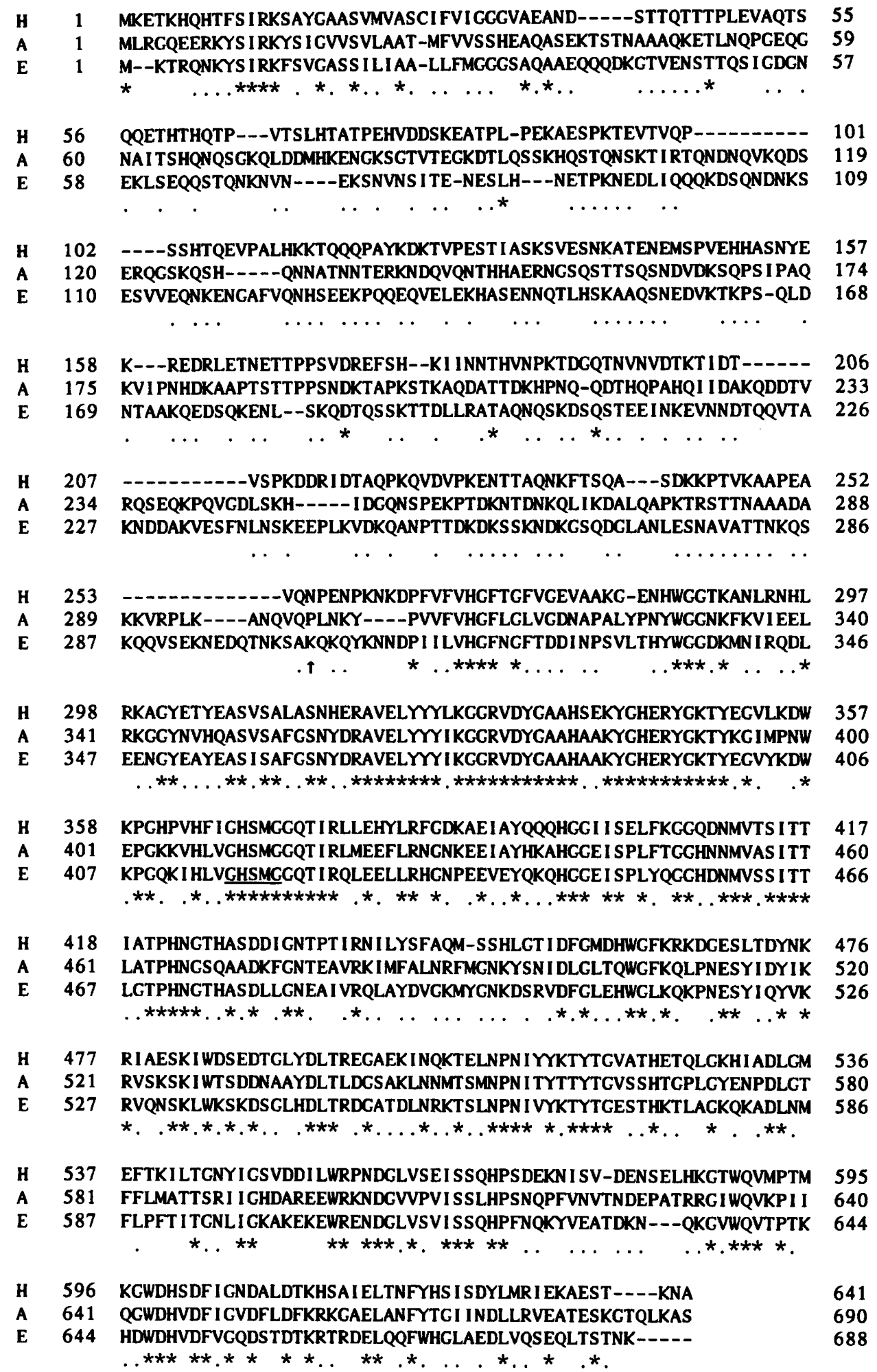

Fig. 4. Alignments of amino acid sequences of lipases from: H, S. hyicus subsp. hyicus DSM 20459 (Gotz et al., 1985); A, S. aureus PS54 (Lee \& Iandolo, 1985); and E, S. epidermidis 9 (this study). Sequences were derived from DNA sequences and each contains a putative signal sequence. The amino acid sequences were aligned using the multiple alignment program CLUSTAL 4 (Higgins \& Sharp, 1989). *, Identical residues; ., conservative amino acid replacements; $\uparrow$, lysine residue dividing N- and C-terminal regions. The consensus sequence containing a serine residue is underlined. 


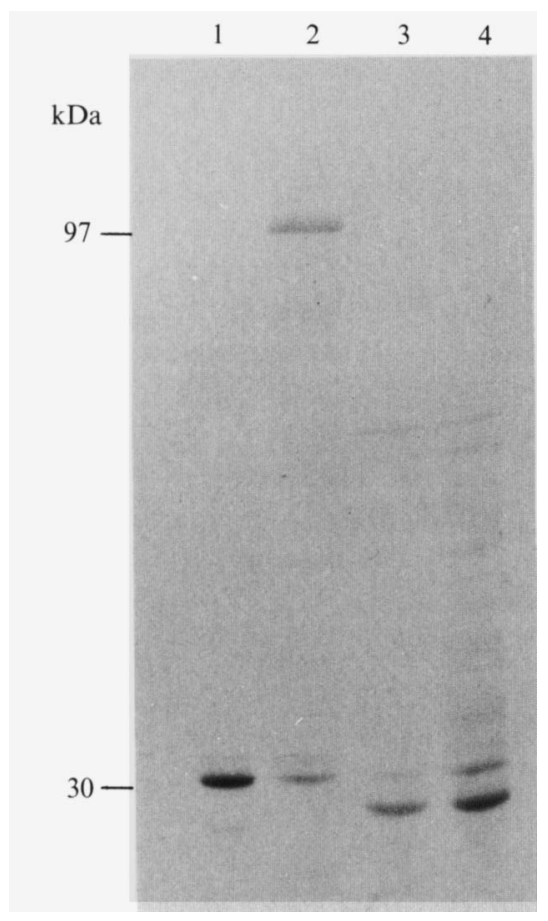

Fig. 5. Autoradiograph of plasmid-encoded polypeptides in E. coli minicells. Track 1, pBR322; track 2, pUL5000; tracks 3 and 4, pUL5000gehC: :Tn5.

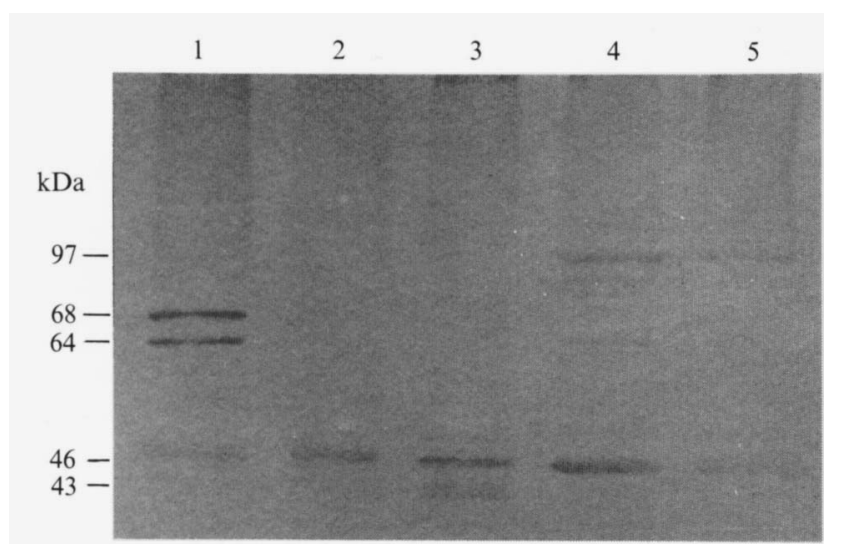

Fig. 6. Immunoblot of proteins $(6 \mu \mathrm{g}$ per track) in culture supernatant fluids of $S$. epidermidis 9 at various culture incubation times. Tracks 1 , 2 and 3 (medium A) 4, 6 and $8 \mathrm{~h}$ incubation, respectively; tracks 4 and 5 (medium B) 5 and $9 \mathrm{~h}$ incubation, respectively.

form during gel-filtration (Tyski et al., 1983). The situation was further complicated as a result of the partial degradation of the lipase by $S$. epidermidis proteinase(s). The latter problem was only apparent after lipase purification had been achieved, and antiserum had been raised and used in Western blotting.

Results suggest that it is possible to purify different molecular mass forms of $S$. epidermidis lipase depending on the lipase species in the culture supernatant fluid. In turn, this will depend on the incubation time at which cultures are harvested during batch culture, and levels of proteolytic activity. The presence of several molecular mass forms of lipase would also influence the lipase yield and specific activity resulting from purification. In the present study, a $43 \mathrm{kDa}$ lipase was purified from $S$. epidermidis 9 culture supernatant fluid. Lipases produced by other staphylococcal species are of a similar molecular mass (43-46 kDa) (Jurgens et al., 1981; Tyski et al., 1983; Van Oort et al., 1989). The nature of the $51 \mathrm{kDa}$ protein which co-purified with the lipase is unclear and requires further investigation.

The $S$. epidermidis 9 lipase gene $(g e h C)$ was cloned in $\lambda$ L47.1 and expressed in E. coli. The gene was subcloned in pUL5000, localized by transposon Tn 5 mutagenesis and the nucleotide sequence determined. From the Tn 5 mutagenesis data, it appeared unlikely that the $2.5 \mathrm{~kb}$ HindIII fragment in pUL5000 would be sufficient to encode lipase activity because the $5^{\prime}$ end of gehC is located on the adjacent $1.2 \mathrm{~kb}$ HindIII fragment (Fig. 2). Lipase activity was detected, however, when the $2.5 \mathrm{~kb}$ $H$ indIII fragment was cloned in $\mathrm{pIC} 20 \mathrm{H}$ in one orientation, forming pUL5003. Examination of the nucleotide sequence of $g e h C$ indicated that an in-frame translational fusion would occur between lacZ and gehC. It is likely, therefore, that the lipase expressed from pUL5003 was a fusion protein formed between $\beta$-galactosidase and lipase. Lipase activity was not detected when the $1.2 \mathrm{~kb}$ $H$ indIII and $1.55 \mathrm{~kb} E c o \mathrm{RV}$ fragments were subcloned in either orientation in $\mathrm{pIC} 20 \mathrm{H}$. This was not surprising because these fragments do not contain the serine residue proposed to participate in either substrate binding or catalytic activity of lipases (Brady et al., 1990; Winkler $e t$ al., 1990).

The molecular mass of the lipase encoded by $g e h C$, as predicted from the nucleotide sequence, was $77 \mathrm{kDa}$. Evidence indicating that the $97 \mathrm{kDa}$ protein is the $g e h C$ translation product and that the $77 \mathrm{kDa}$ lipase migrates anomalously on SDS-PAGE gels include the following: (1) E. coli minicells contained a single protein of $97 \mathrm{kDa}$ in addition to vector-encoded polypeptides and this reacted with anti-lipase serum; (2) insertion of Tn5 within the $g e h C$ open reading frame abolished both lipase activity and the $97 \mathrm{kDa}$ protein in $E$. coli minicells; and (3) lipolytic extracts of $E$. coli containing pUL5000 or pUL5008 contained an immunoreactive protein of $97 \mathrm{kDa}$, which was absent in Tn5 mutants and in vectorcontaining strains. Furthermore, it is likely that the anomaly occurs at the $\mathrm{N}$-terminal region of the lipase because the molecular mass of the processed $43 \mathrm{kDa}$ lipase, as determined by SDS-PAGE, is the same as that predicted from the nucleotide sequence downstream of the cleavage site.

In addition to small polypeptides, the $97 \mathrm{kDa}$ protein was produced in lipolytic $S$. epidermidis 9 cultures (in 
medium B) in which no extracellular proteinase was detected. In cultures with detectable lipase and proteinase activities (in medium A), not only was the lipase activity reduced after proteinase was produced (after $6 \mathrm{~h}$ incubation), but the $97 \mathrm{kDa}$ polypeptide was not detected by Western blotting. In this case, immunoreactive polypeptides were in the range $68-43 \mathrm{kDa}$. The results indicate that $S$. epidermidis 9 produces a lipase of $97 \mathrm{kDa}$, as determined by SDS-PAGE, which is sequentially degraded by $S$. epidermidis protelytic activity to a $43 \mathrm{kDa}$ form. It is likely that undetectable levels of proteolytic activity in medium B caused limited lipase degradation.

A similar result was obtained with Staphylococcus hyicus lipase (Gotz et al., 1985; Van Oort et al., 1989). The $S$. hyicus lipase gene was cloned and expressed in Staphylococcus carnosus. Although a $71 \mathrm{kDa}$ polypeptide was predicted from the nucleotide sequence, the molecular mass of the lipase as determined by SDS-PAGE was $86 \mathrm{kDa}$. Active lipases in the range $86-46 \mathrm{kDa}$ were observed during purification procedures. In $S$. hyicus cultures, a $46 \mathrm{kDa}$ lipase was detected. It was concluded that $S$. hyicus lipase is secreted as a pro-protein of $86 \mathrm{kDa}$ and that a hydrophilic N-terminal region of 230 residues is required for efficient secretion of the lipase. Proteolytic cleavage of the pro-lipase occurs with the formation of a $46 \mathrm{kDa}$ mature lipase in $S$. hyicus cultures.

Semi-quantitative methods were developed during this study for the detection of lipase-expressing recombinants. Agars containing lipase substrates were used for overlaying plaques or for plating $E$. coli directly. A combination of tributyrin and triolein agars was used. Although the former is very sensitive to lipase activity, it is not specific, as esterases cause its hydrolysis. Triolein was therefore used for confirming lipase activity. This approach may be used for cloning lipase genes from other sources.

Information obtained from this investigation will facilitate the construction of lipase-deficient isogenic mutants of $S$. epidermidis 9 by allele-replacement mutagenesis. Studies comparing lipase-negative mutants with an otherwise isogenic strain will provide information concerning the ecological and possible pathogenic role of the lipase.

We are grateful to E. Ingham and G. Dougan for antiserum production and assistance with minicell experiments, respectively. The amino acid sequencing was performed by the SERC amino acid sequencing service at the University of Leeds. This work was financially supported by the Leeds Foundation for Dermatological Research.

\section{References}

APPLEYARD, R. K. (1954). Segregation of new lysogenic types during growth of a doubly lysogenic strain derived from Escherichia coli K12. Genetics 39, 440-452.
ARVidson, S. O. (1983). Extracellular enzymes from Staphylococcus aureus. In Staphylococci and Staphylococcal Infections, vol. 2, pp. 745-808. Edited by C. S. F. Easmon \& C. Adlam. London: Academic Press.

BaIRD-PARKer, A. C. (1990). The staphylococci: an introduction. Journal of Applied Bacteriology Symposium Supplement 69S, 1S-8S.

Bolivar, F., Rodriguez, R. L., Greene, P. J., Betlach, M. C., Heynecker, H. L., Boyer, H. W., Crosa, J. H. \& Falkow, S. (1977). Construction and characterization of new cloning vehicles. II. A multipurpose cloning system. Gene 2, 95-113.

BRADFORD, M. M. (1976). A rapid and sensitive method for the quantitation of microgram quantities of protein utilizing the principle of protein-dye binding. Analytical Biochemistry 72, 248-254.

Brady, L., Brzozowski, A. M., Derewenda, Z. S., Dodson, E., Dodson, G., Tolloy, S., Turkenburg, J. P., Christiansen, L., Huge-Jensen, B., Norskov, L., Thim, L. \& Menge, U. (1990). A serine protease triad forms the catalytic centre of a triacylglycerol lipase. Nature, London 343, 767-770.

Coleman, D. C. \& Foster, T. J. (1981). Analysis of the reduction in expression of tetracycline resistance determined by transposon $\operatorname{Tn} 10$ in the multicopy state. Molecular and General Genetics 182, 171-177.

Dougan, G. \& SherratT, D. (1977). The transposon Tnl as a probe for studying ColE1 structure and function. Molecular and General Genetics 151, 151-160.

Gotz, F., Popp, F., Korn, E. \& Schleifer, K. H. (1985). Complete nucleotide sequence of the lipase gene from Staphylococcus hyicus cloned in Staphylococcus carnosus. Nucleic Acids Research 13, 5895-5906.

HigGins, D. G. \& Sharp, P. M. (1989). Fast and sensitive multiple sequence alignments on a microcomputer. CABIOS 5, 151-153.

Ingham, E., Holland, K. T., Gowland, G. \& CunlifFe, W. J. (1981). Partial purification and characterization of lipase (EC 3.1.1.3) from Propionibacterium acnes. Journal of General Microbiology 124, 393-401.

Ingham, E., Holland, K. T., Gowland, G. \& CunlifFe, W. J. (1984). Difficulties in producing antibodies to purified Propionibacterium acnes exocellular enzymes. British Journal of Dermatology 110, 61-66.

Ingham, E., Eady, E. A., Holland, K. T. \& Gowland, G. (1985). Effects of tampon materials on the in-vitro physiology of a toxic shock syndrome strain of Staphylococcus aureus 20, 87-95.

JuRgens, D., Huser, H., BrunNER, H. \& FeHrenbaCH, F. J. (1981). Purification and characterization of Staphylococcus aureus lipase. FEMS Microbiology Letters 12, 195-199.

Kimura, H., Kitamura, T. \& Tsuji, M. (1972). Studies on human pancreatic lipase. I. Interconversion between low and high molecular weight forms of human pancreatic lipase. Biochimica et Biophysica Acta 270, 307-316.

KLoos, W. E. (1990). Systematics and the natural history of staphylococci. 1. Journal of Applied Bacteriology Symposium Supplement 69S, 25S-37S.

KLOOS, W. E. \& SchleIFER, K. H. (1975). Simplified scheme for routine identification of human Staphylococcus species. Journal of Clinical Microbiology 1, 82-88.

LAEMMLI, U. K. (1970). Cleavage of structural proteins during the assembly of the head of bacteriophage T4. Nature, London 227, $680-685$.

LEE, C. Y. \& IANDOLO, J. J. (1985). Lysogenic conversion of staphylococcal lipase is caused by insertion of the bacteriophage L 54a genome into the lipase structural gene. Journal of Bacteriology 166, 385-391.

Maniatis, T., Fritsch, E. F. \& SambrooK, J. (1982). Molecular Cloning. A Laboratory Manual. Cold Spring Harbor, NY: Cold Spring Harbor Laboratory.

MarSh, J. L., Erfle, M. \& Wykes, E. J. (1984). The pIC plasmid and phage vectors with versatile cloning sites for recombinant selection by insertional inactivation. Gene 32, 481-485.

MILLER, J. H. (1972). Experiments in Molecular Genetics. Cold Spring Harbor, NY: Cold Spring Harbor Laboratory.

NeU, H. C. \& HePpel, L. A. (1965). The release of enzymes from Escherichia coli by osmotic shock and during the formation of spheroplasts. Journal of Biological Chemistry 240, 3685-3692. 
O'Reilly, M., de Azavedo, J. C. S., Kennedy, S. \& Foster, T. J. (1986). Inactivation of the alpha-haemolysin of Staphylococcus aureus $8325-4$ by site-directed mutagenesis and studies on the expression of its haemolysins. Microbial Pathogenesis 1, 125-138.

O’TOOLE, P. W. \& Foster, T. J. (1986). Molecular cloning and expression of the epidermolytic toxin A gene of Staphylococcus aureus. Microbial Pathogenesis 1, 583-594.

Patel, A. H., Nowlon, P., Weavers, E. D. \& Foster, T. (1987). Virulence of protein A-deficient and alpha-toxin-deficient mutants of Staphylococcus aureus isolated by allele replacement. Infection and Immunity 55, 3103-3110.

Perlman, D. \& Halvorson, H. O. (1983). A putative signal peptidase recognition site and sequence in eukaryotic and prokaryotic signal peptides. Journal of Molecular Biology 167, 391-409.

Phonimdaeng, P., O'Reilly, M., Nowlan, P., Bramley, A. J. \& Foster, T. J. (1990). The coagulase of Staphylococcus aureus 8325-4. Sequence analysis and virulence of site-specific coagulase-deficient mutants. Molecular Microbiology 4, 393-404.

Pulverer, G., Peters, G. \& Schumacher-Perdreau, F. (1987). Coagulase-negative staphylococci. Zentralblatt für Bakteriologie, Mikrobiologie und Hygiene Series A 264, 1-28.
Russell, R. R. B., Colmman, D. \& Dougan, G. (1985). Expression of a gene for glucan-binding from Streptococcus mutans in Escherichia coli. Journal of General Microbiology 131, 295-299.

SaNGER, F., Nicklen, S. \& Coulson, A. R. (1977). DNA sequencing with chain-terminating inhibitors. Proceedings of the National Academy of Sciences of the United States of America 74, 5463-5467.

TAYLOR, D. \& HollaND, K. T. (1989). Amino acid requirements for the growth and production of some exocellular products of Staphylococcus aureus. Journal of Applied Bacteriology 66, 319-329

TYSKI, S., HRYNIEWICZ, W. \& JeLJASZEWICZ, J. (1983). Purification and some properties of the staphylococcal extracellular lipase. Biochimica et Biophysica Acta 749, 312-317.

VADEHRA, D. V. (1974). Staphylococcal lipases. Lipids 9, 158-165.

Van Oort, M. G., Deveer, A. M. Th. J., Dijkman, R., TJeenk, M. L., VerheIJ, H. M., DE HaAs, G. H., WenziG, E. \& Gotz, F. (1989). Purification and substrate specificity of Staphylococcus hyicus lipase. Biochemistry 28, 9278-9285.

Wain-Hobson, S., S., Sonigo, P., Danos, O., Cole, S. \& Alizon, M. (1985). Nucleotide sequence of the AIDS virus, LAV. Cell 40, 9-17.

Winkler, F. K., D'ARCY, A. \& HunZIKER, W. (1990). Structure of human pancreatic lipase. Nature, London 343, 771-774. 